\title{
Nigerian child learning styles: a teaching strategy for achieving effective education in Nigeria
}

\author{
M. N. Modebelu*, F. K. Igwebuike
}

Department Of Agricultural And Home-Econmics Education, Michael Okpara University Of Agriculture, Umudike, Abia State Of Nigeria *Phone: 08035050452

*E-mail address: meloodyne@yahoo.co.uk

\section{ABSTRACT}

This study investigated the Nigerian child learning styles effective education in Nigeria. It was a survey design carried o Anambra State. Respondents were made up of 1000 classroo sampling. Four research questions guided the study. A f ur-point scale que ronnaire containing 28 items, validated by experts in Educational administration upervision and Educational psychology was used for data collection. Data analysis was done using f uency distri ution tables and mean scores. The findings revealed that secondary school teachers vigeria ossess characteristics of good teaching to a high extent, eight learning styles -effective no were identified. The identified learning styles were applied to a low extent an in aptraints responsible for the low application were also identified. Recommendations were $\mathrm{m}$ de $\mathrm{dich}$ that regular seminars and workshops should be organized to up-date these achers, e ecially on the areas of learning styles and their effective application to encourage 1 arner entred e ication.

Keywords: Education; Nigeri thin the the thing strategy; effective education

\section{INTRODUGION}

Educatio seneral seen as an instrument par excellent that every nation requires for achievip effect educan for sustainable development. Education according to Ukeje, $\mathrm{Aka}$ ogu a $\mathrm{Ndu} 2$ ) is the process by which people are prepared to live effectively and ef tly on their own environment. This implies that education is the only veritable instru. tor anrieving quality and effective citizenship in any society. The education that could $\mathrm{p}_{\mathrm{r}} \mathrm{re}$ and produce quality citizens is said to be effective education. Effective education a cording to Hornby (2004) is the process of producing an intended result, fulfilling a function or even something being operative. Effective education therefore is that education is capable of producing intended results, and capable of fulfilling its functions. Nigerian education is designed to achieve four major goals in every individual that has the opportunity of passing through it. The goals are:

Inculcation of national consciousness and unity to the citizens.

Inculcation of right type of values and attitudes as a means of survival of the individuals and the Nigerian society; 
Training of the mid in understanding of the world around; and

The acquisition of appropriate skills, abilities and competencies both mental and physical as equipment for the individual to live in and contribute to the development of the society (FRN, 2004: 8).

At any level of education, unless the aforementioned goals are successfully inculcated into the citizens, that education is ineffective. No matter how lofty the curriculum might be, if the quality of the teacher and his teaching is not adequate and effective then that education would like be ineffective. No wonder Ukeje (1986) emphasizes that no education system can rise above its teachers. Teachers are group of individuals, who have undergon red professional training in education at appropriate levels and are capable of impar knowledge, attitudes and skills to the learners. It is the duty of the teachers a lp organi learning experiences, and to put them into effective use. The teachers sho help learr achieve the goals of education through quality teaching/ instruction.

Teaching as the major role of Nigerian teacher is the systemat tion and or:anized process of transmitting right knowledge, values, attitudes and $s^{\prime}$ in ordanc $w i t h$ the professional principles. Those who do not perform the act in cordance nunciples are therefore not teachers (TRC, 2002). It is a known fact t at hing and, earning go on simultaneously. This implies that quality teaching brings but qua learning. Some of the qualities of good teaching include:

- Good teaching is oriented towards the goals

- Good teaching is innovative i.e. tries new improvement;

- It utilizes adequate teaching methods 1 ills;

- It develops and encourages positive at tude as friendliness and cooperation;

- It provides the learner with activities $m$ ch stimulates learning;

- It strives to know and und crst the lea her and his learning environment;

- It recognizes that no t learn is are equally gifted:

- Good teaching asce ins has taken place at one stage before proceeding to the next stage

- Good teachin reo izes teach s as instrument for enhancement of learning.

- Teachers wh posso hese qualities and put them into action should summarizingly ensure a ality learning Ke \& Onyemerekeya, 2008).

Learn a cco amg $\$$ Wikipedia (2009) is a change in behavior or performance which is as a result xperien and practice which makes an individual face later situations differ .... This ch according to Stahl (2009) should lead to improvement. It is a process tha invol as devel pment of habits, attitudes, perceptions, interests, preferences, social adjus elopment of skills and acquisitions of knowledge. It is therefore the duty of a tea $r$ to ensure that every learner is a potential achiever through quality teaching and learning. Aity teaching is geared towards effective learning.

Quality learning should in addition to application of teaching methods/skills probe and identify various learning styles of learners. Anyachebelu (2005) observes that every learner has its own characteristics make-ups that either hinder or promote his/her rate of intellectual functioning. Okeke (2008) notes that rate of learners assimilation of a given subject matter lies greatly on the individual learners learning styles.

Harris (2010) defines learning styles as the learners' unique ways of grasping, organizing and transforming information into useful knowledge and action. Every learner therefore has a unique and recognizable pattern of learning behavior. Learners tend to adopt 
more than one learning styles in learning and this is dependent on the nature of topic and mode of instruction. This implies that teachers should incorporate learners learning styles as part of their teaching skills and methods.

Morsin (2010) identifies the following learning styles: collaborative learning style, reflective learning style, avoidant learning style, dependent learning style independent learning style theorist learning style, pragramatist learning style, sensing learning style,and intuitive learning style.

Haris (2010) also recommended another four learning styles for effective education to include: visual learning style, verbal learning style, sequential learning style, and ${ }^{-1}$ obal learning style Intuitive Learning Style is adopted by learners who prefer aiscon $g$ possibilities and relationships. This encourages innovation and eschews repe on. Learn grasp new concepts readily and are more at home with abstraction/mathema ics to ulae.

Sensing Learning Style is good for learners like solving problem by well-o blis ed methods. They resent being tested on materials that has not be explicit cover

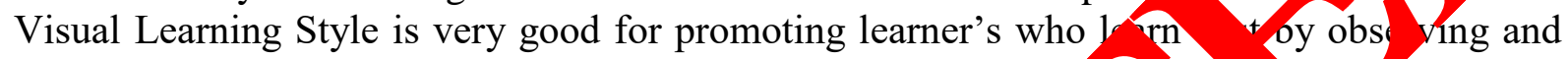
seeing the picture, diagrams, i.e. visual aids. Collaborative $/$ arning $S_{4}$ is pical of a learner who feels that ideas are best shared with other lo an in the o srooms. Such learners like to cooperate with teachers in their process on earn Classrom is seen as a place of social interaction as well as content learnin. Style indicates learners who do not trust on their abilities and there ore must be carr ed along. Independent Learning Style concerns learners who are capable f thinking f/ $r$ themselves. They like to explore on their own. Avoidant Learning Style appli o learners who adopt dislike syndrome towards a subjects i.e. laisez-faire learner Reflectiv ng Style concerns process of taking time to consider all alternatives $b$ aking decision or assimilating. Activist Learning Style entails interest in novelty lear ere pu Theorist Learning Style involves linkages and relationships and Praxmatist L arning Style involves using need to ensure application of new material enc ante Impli tion of these learning styles to the teachers' teaching is that teachers sb be conversay, with their learners learning experiences, learning styles and know on spry om combination to motivate students learning. Teachers should also $\mathrm{kp}$ that lear o styles are equally teaching skills and at such should be made part of the te. ing methy as/skills. The problem of the study is that Nigerian education appears aneffect products seem not properly educated and developed for effective citizer ship. This coulo due to inadequate teaching methods and skills which seem not to reflect igeria bild learning styles.

\section{2. $D$ URP E OF E STUDY effective ation in Nigeria.}

study examined Nigerian child learning styles as teaching strategy for achieving

\section{1. Research Questions}

Four research questions guided the study:

1. To what extent do secondary school teachers possess characteristics of good teaching?

2. To what extent are teachers conversant with various Nigerian child learning styles?

3. To what extent do teachers apply the learning styles as teaching strategies?

4. What are the constraints to teachers' effective application the learning styles as teaching strategies? 


\section{2. Methodology}

The study adopted a descriptive survey design. The descriptive survey is very good in eliciting responses from respondents on prevailing issues.

\section{Population:}

The population of the study consisted of five thousand eight hundred $(5,800)$ classroom (2,278 males and 3,522 females) teachers in the two hundred and fifty eight (258) public secondary schools in the 21 Local Government areas within the five (5) Education zones in Anambra State.

\section{3. Sampling Technique}

One thousand $(1,000)$ respondents (392 male and 608 female tea nens) we amp cd through proportionate stratified sampling techniques from 25 publi secon ary sc $s$ in Anambra State.

\section{4. Instrument for Data Collection}

The instrument for data collection was research devo ed questionnaire titled "Learning styles as teaching strategies (LSATS)". It contained 28 s posed to provide information for the four research questions. It was b ilt on 4-point rating scale of Very High Extent (VHE) (4-points), High Extent (3 points), L Extent (L) -2 points and Very Low Extent (VLE) -1 point.

\subsection{Validation of the instrument}

Two experts in the Educational Adminis con/sy pervision and Educational Psychology validated the instrument on conte face v idity. Suggestions reflected in the final draft of the instrument.

\section{6. Reliability of the in trument}

Reliability inde $\mathrm{va}$ of $0.85,0.80,0.75$ and 0.80 were obtained from the pilot test data subjected to $\mathrm{M}$ i half re ility technique for the four research questions.

\section{7. Methor fDat Jollection}

The resea rs adm nistered 1000 copies of the LSATS questionnaire to 1000 sampled teach is the ance of two research assistants. Analysis was made based on 995 co of t LSATS questionnaire returned (about $99.5 \%$ return).

\section{8. Mt d of Data Analysis}

The d.ecision rule was that items that score 2.50 and above were regarded as positive and high extent responses while items that score below 2.50 were negative responses and treated as low extent for the research questions 1, 2 and 3. For research question 4, positive responses were treated as agree and negative responses treated as disagree. 


\section{RESULTS}

Results in Table 1, reveal classroom teachers' mean scores responses on teaching strategy for enhancing Nigeria child learning. Four (4) out of the seven (7) items enumerated scored above 2-50 indicating classroom teachers general agreement that teachers possess the four characteristics of the teaching strategy items to high extent. While 3 items $(2,5$ and 6$)$ scored below 2-50 indicating that teachers possess the teaching strategy items to a low extent. Therefore, only 4 items (1, 3, 4 and 7) were identified as the characteristics of good teaching strategy possessed by the teachers.

Research question 1: To what extent do secondary school teachers characteristics of quality teaching?

Table 1. Mean scores analysis of teachers on characteristics of good tea ning strate

\begin{tabular}{|c|c|c|c|c|c|c|c|}
\hline \multirow{2}{*}{$\mathbf{S} / \mathbf{N}$} & \multirow{2}{*}{$\begin{array}{l}\text { To what extent are these the } \\
\text { characteristics of good teaching }\end{array}$} & & & & & & Remar \\
\hline & & $\begin{array}{c}\text { VHE } \\
4\end{array}$ & & & & $\mathrm{X}$ & \\
\hline 1. & Good teaching is goal oriented & $\begin{array}{l}(505 \\
202\end{array}$ & $\begin{array}{c}(300) \\
900\end{array}$ & $\begin{array}{l}(150) \\
100\end{array}$ & $\begin{array}{c}(45) \\
40\end{array}$ & 3.27 & $\begin{array}{l}\text { High } \\
\text { Extent } \\
\text { (H.E) }\end{array}$ \\
\hline 2. & Good teaching is innovative & & & $\begin{array}{l}(365) \\
2010\end{array}$ & $\begin{array}{c}(605) \\
605\end{array}$ & 1.92 & H.E \\
\hline 3. & $\begin{array}{l}\text { Good teaching develops positive } \\
\text { behaviours } \\
\text { in learners }\end{array}$ & & - & - & - & 4.00 & H.E \\
\hline 4. & Go & $\begin{array}{l}(450) \\
1800\end{array}$ & $\begin{array}{l}(490) \\
1470\end{array}$ & $\begin{array}{c}(43) \\
86\end{array}$ & $\begin{array}{c}(17) \\
17\end{array}$ & 3.87 & H.E \\
\hline 5. & $\begin{array}{l}\text { Good tea } \\
\text { learning }\end{array}$ & $\begin{array}{c}(100) \\
400\end{array}$ & $\begin{array}{c}(120) \\
6\end{array}$ & $\begin{array}{c}(611) \\
012\end{array}$ & $\begin{array}{c}(87) \\
87\end{array}$ & 1.91 & H.E \\
\hline 6. & $\begin{array}{l}\text { Good te? hing } \\
\text { are } \\
\text { equally g. }\end{array}$ & $\begin{array}{l}(485) \\
2020\end{array}$ & $\begin{array}{c}(102) \\
306\end{array}$ & $\begin{array}{l}(25) \\
1222\end{array}$ & $\begin{array}{c}(107) \\
1.92\end{array}$ & 1.92 & $\begin{array}{c}\text { Low } \\
\text { Extent } \\
\text { (L.E) }\end{array}$ \\
\hline 7 & fective & $\begin{array}{l}(980) \\
3920\end{array}$ & $\begin{array}{c}(20) \\
60\end{array}$ & & & 3.98 & H.E \\
\hline & & & Grand & Mean & & 3.18 & H.E \\
\hline
\end{tabular}

Table 1 with a grand mean of 3.18 indicated classroom teachers general agreement with the seven items enumerated are characteristics of good teachers. Scores below the weighted mean of 2.50 indicated the teachers low extent knowledge of the two out of the seven characteristics of good teaching. Research question 2: To what extent do secondary school teachers know various Nigerian child learning style as a teaching strategy? 
Table 2. Mean scores analysis on knowledge of various Nigerian child learning styles?

\begin{tabular}{|c|c|c|c|c|c|c|c|}
\hline \multirow{2}{*}{$\mathbf{S} / \mathbf{N}$} & \multirow{2}{*}{$\begin{array}{l}\text { To what extent do teacher know } \\
\text { these Nigerian child learning styles } \\
\text { as a teaching strategy }\end{array}$} & \multicolumn{5}{|c|}{ TEACHERS RESPONSES } & \multirow{2}{*}{ Remarks } \\
\hline & & $\begin{array}{c}\text { VHE } \\
4\end{array}$ & $\begin{array}{c}\mathrm{HE} \\
3\end{array}$ & $\begin{array}{c}\mathrm{LE} \\
2\end{array}$ & $\begin{array}{c}\text { VLE } \\
1\end{array}$ & $X$ & \\
\hline 8. & Collaborative learning styles & $\begin{array}{l}(919) \\
3676\end{array}$ & $\begin{array}{l}(81) \\
243\end{array}$ & - & - & 3,91 & $\begin{array}{l}\text { High } \\
\text { Extent }\end{array}$ \\
\hline 9. & Intuitive Learning style & $\begin{array}{c}(26) \\
104\end{array}$ & $\begin{array}{c}(144) \\
132\end{array}$ & $\begin{array}{l}(800) \\
1600\end{array}$ & & & \\
\hline 10. & Visual Learning style & - & $\begin{array}{l}(900) \\
2700\end{array}$ & & & & \\
\hline 11. & Theorists Learning style & - & & & & & L.E \\
\hline 12. & Independent Learning style & $\begin{array}{l}(263) \\
1052\end{array}$ & 1240 & & $(22)^{\prime}$ & 2.92 & H.E \\
\hline 13. & Pragmatic Learning style & & $\begin{array}{c}(2) \\
6\end{array}$ & $\begin{array}{l}(900) \\
800\end{array}$ & $\begin{array}{c}(98) \\
98\end{array}$ & 1.90 & L.E \\
\hline 14. & Sensing Learning style & & & $\begin{array}{c}(319) \\
638\end{array}$ & $\begin{array}{c}(5) \\
5\end{array}$ & 2.68 & H.E \\
\hline 15. & Sequencing Learning style & & $\begin{array}{l}11) \\
44\end{array}$ & $\begin{array}{l}(979) \\
2937\end{array}$ & $\begin{array}{c}(10) \\
10\end{array}$ & 2.19 & L.E \\
\hline & & & Grand & Mean & & 1.95 & L.E \\
\hline
\end{tabular}

Result in Taore 2 indica tbrat a low grand mean of 1.95 indicating secondary school teachers low xtent nowledge of Nigerian child learning styles. Their ignorance seems highest witin ite as (11 nd 13) which are theorist and style pragmatic learning styles. This implies that ma ty of sigerian child learning styles are unfamiliar with the teachers. Rese ach stion what extent do teachers apply learning styles as teaching styles?

Tab Mean score/rating analysis of teachers responses on extent of teachers apply of learning styles as teaching strategy.

\begin{tabular}{|c|c|c|c|c|c|c|c|}
\hline \multirow{3}{*}{ S/N } & \multirow{2}{*}{$\begin{array}{c}\text { Extent of application of these } \\
\text { learning style as teaching } \\
\text { strategy }\end{array}$} & \multicolumn{7}{|c|}{ TEACHERS RESPONSES } & \multirow{2}{*}{ Remarks } \\
\cline { 3 - 8 } & $\begin{array}{c}\text { VHE } \\
4\end{array}$ & HE & $\begin{array}{c}\text { LE } \\
2\end{array}$ & $\begin{array}{c}\text { VE } \\
1\end{array}$ & X & \\
\hline \multirow{2}{*}{16.} & Collaborative learning style & $\begin{array}{c}(500) \\
2508\end{array}$ & $\begin{array}{c}(450) \\
1350\end{array}$ & $\begin{array}{c}(40) \\
80\end{array}$ & $\begin{array}{c}(8) \\
8\end{array}$ & 3.45 & $\begin{array}{c}\text { High } \\
\text { Extent } \\
\text { (H.E) }\end{array}$ \\
\hline
\end{tabular}




\begin{tabular}{|c|c|c|c|c|c|c|c|}
\hline 17. & Intuitive learning style & - & $\begin{array}{l}(40) \\
120\end{array}$ & $\begin{array}{c}(460) \\
920\end{array}$ & $\begin{array}{c}(500) \\
500\end{array}$ & 1.54 & $\begin{array}{c}\text { Low } \\
\text { Extent } \\
\text { (L.E) }\end{array}$ \\
\hline 18. & Theorist learning style & - & - & - & $(1000)$ & 1.00 & L.E \\
\hline 19. & Pragmatic learning style & - & - & $\begin{array}{c}(1000) \\
2000\end{array}$ & & 2.00 & L.E \\
\hline 20. & Independent learning style & $\begin{array}{c}(13) \\
52\end{array}$ & $\begin{array}{c}(100) \\
300\end{array}$ & $\begin{array}{l}(751) \\
1502\end{array}$ & $\begin{array}{c}(36) \\
36\end{array}$ & 1.89 & \\
\hline 21. & Visual learning style & $\begin{array}{l}(911) \\
2644\end{array}$ & $\begin{array}{l}(77) \\
231\end{array}$ & $\begin{array}{c}(10) \\
29\end{array}$ & (2) & & \\
\hline 23. & Sequencing learning style & $\begin{array}{c}\text { (2) } \\
8\end{array}$ & $\begin{array}{l}(25) \\
105\end{array}$ & $\begin{array}{l}(808) \\
1616\end{array}$ & & & \\
\hline
\end{tabular}

Result in Table 3 above shows grand mean of 200 indicated teas crs' teachers' general disagreement with the eight items. This implies tha the learning styles are applied to a low extent by teachers of secondary schools as teaching rategy. Re earch Question 4: What are the constraints to secondary school teachers' effecti onlicat on of learners learning styles as teaching strategy?

Table 4. What are the constraints to teachers ff cctive,pplication learning styles as teaching

\begin{tabular}{|c|c|c|c|c|c|c|c|}
\hline \multirow{2}{*}{$\mathbf{S} / \mathbf{N}$} & $\sqrt{2}$ & & $\mathbf{A}$ & D & SD & & Remarks \\
\hline & 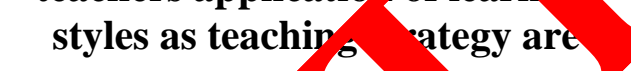 & 4 & 3 & 2 & 1 & & \\
\hline 24. & & $\begin{array}{c}(12) \\
48\end{array}$ & $\begin{array}{l}(916) \\
2748\end{array}$ & $\begin{array}{c}(45) \\
90\end{array}$ & $\begin{array}{c}(27) \\
27\end{array}$ & 2.91 & Agreed \\
\hline 25. & & $\begin{array}{c}(259) \\
1036\end{array}$ & $\begin{array}{l}(60) \\
204\end{array}$ & $\begin{array}{l}(61) \\
122\end{array}$ & & 3.20 & Agreed \\
\hline 26. & of skills of & $\begin{array}{c}(1000) \\
4000\end{array}$ & - & - & - & 4.00 & Agreed \\
\hline 27. & $\begin{array}{l}\text { Ina quate access to current } \\
\text { materials for } \\
\text { up-dating }\end{array}$ & $\begin{array}{c}(1000) \\
4000\end{array}$ & - & - & - & 4.00 & Agreed \\
\hline \multirow[t]{2}{*}{28.} & $\begin{array}{l}\text { Inadequate motivation of teacher for } \\
\text { innovativeness }\end{array}$ & $\begin{array}{l}(536) \\
2144\end{array}$ & $\begin{array}{l}(430) \\
1290\end{array}$ & $\begin{array}{l}(24) \\
48\end{array}$ & $\begin{array}{c}(10) \\
10\end{array}$ & 3.49 & Agreed \\
\hline & & & \multicolumn{3}{|c|}{ Grand Mean } & 3.52 & \\
\hline
\end{tabular}


The result in Table 4 reveals grand mean score of 3.52 for teachers, indicating general agreement that the five items enumerated could serve as are constraints to secondary school teachers' application for Nigerian child learning styles as a teaching strategy.

\section{DISCUSSION}

Effective education has been recognized as an instrument of social transformation. Teachers are seen as the agent through which this their teaching quality. Good teaching has many characteristics that supports and enhances achievement of education goals I This qu teaching incorporates teaching methods, skills and learning styles.

Result of findings in Table 1 showed that secondary school teachers mener oreed th the seven items on the Table 1 are characteristics of good teaching for a cainment $d$ fect ve education. The findings are in line with Uche and Onyemerekeya $(20$, that nntific about fifteen qualities of a good teaching to include: goals oriented, ans "ation o citizens, identification of learners/individual difference in learning, recog izing leà s lea ning styles etc. The findings also disagreed that items 2 and 5 (i.e. tear in antails in ativeness, and incorporates learning styles) as characteristics of teachin Tea seem to believe that innovativeness is not directly related to teaching. This oumbe one o / teaching is not very effective. Result in Table 2 ig ntified various Drgerian child learning styles to be collaborative, intuitive, visual, independ t learning s $\mathrm{yles}$, etc.

These findings support the earlier works of Corsin (2/10) and Haris (2010) that recommended various learning styles, that good tea nould incorporate for quality teaching and learning. Finding also showed items out of the eight that is theorist, pragmatic and sequencing learning styles are cee a low extent by teachers as Nigerian Child Learning styles. This is in contrary reconmendation of Morsin and Harris as enumerated in Table 2. The grar a m of teac ers responses on the Table 2 confirmed that teachers generally do not kne ario -Nigeria Child Learning styles that could be part of teaching strategy.

Result in Table 3 th low gra mean of 2.30 revealed that secondary school teachers apply learners learni $\mathrm{g} \mathrm{S}_{3}$ to a low cxtent during their teaching. This observation is not surprising since $r$ r y in the ble 2 showed that teachers are not very aware of or familiar with Nigeria Cb Ad learning sty One can hardly apply what he does know. This observation disagree wit $\checkmark$ keke 008 ) that emphasized the importance of application and incorporation learning styles aching d learning as a teaching skills.

$\mathrm{P}$ in 4 ried to identify about five constraints to awareness and effective app cation of learn learning styles during teaching. These included ignorance/inadequate kno dg the fistence of learning styles, inadequate knowledge of their importance, inadec opportunities for up-dating knowledge, poor access to up-dating materials and poor mot on. Stahl (2009) and Anyachebelu (2005) observed that majority of teachers are not well gromed and equipped for the task of teaching at this age of information technology.

\section{Recommendations}

Regular, periodical seminars and workshop should be organized to update these teachers especially on learner centered teaching approach and Nigerian child learning styles. Teachers working conditions should be enhanced to serve as motivation to attend to these workshops on their own sponsorship. 


\section{CONCLUSION}

The study has examined what teaching ought to be in terms of characteristics. It identified level of Secondary School teachers awareness of Nigerian child learning styles and their utilization during teaching to achieve quality education of Nigerian child. Secondary school teachers are knowledgeable of the characteristics of good teaching. But the teachers are not very knowledgeable of various Nigeria Child learning styles. The study observed that teachers in secondary schools apply learning styles to a low extent during the process of teaching and learning. About five constraints to the application of these learning styloc-were identified.

\section{References}

[1] Anyachebelu E. (2005). Educational Psychology for Effective learning in schools. Lagos Papyrus publishers.

[2] Federal Republic of Nigeria - FRN (2004). National po cy ducation. $4^{\text {th }}$ Edition) NERDC.

[3] Haris J., New Definition of Terms. Disability lea ling. Quartify 4(), (2010) 336-342.

[4] Hornby A. S. (2004). Advanced Dictionary for c rent Englis f. Oxford: University Press.

[5] Morsin K. C. (2010). Learning disabilit astrieval on $24^{\text {th }}$ March, 2011 from http://ww.eduforum.org.

[6] Okeke M. H., Educational Jour of Man gement Development 1(1) (2008) 2-6.

[7] Stahl S., Journal of Reviey fEdu ational k search 4(2) (2009) 228-232.

[8] Uche U. W., Onyemer (zuvo,. Teacher Education for Nigerian Tertiary Institution, NUC/N E Mnimu randard Edition. Awka: NUC/Cento Publishers \& Academic Press td.

[9] Ukeje B. O, mbogu G. Vdu A. N. (1992). Educational Administration Enugu: fourth Dir iensio, Publishin,Co. Ltd.

[10] Wikiped 09$). F \eta$ Encyclopedia. Retreived on $4^{\text {th }}$ June, 2011 from

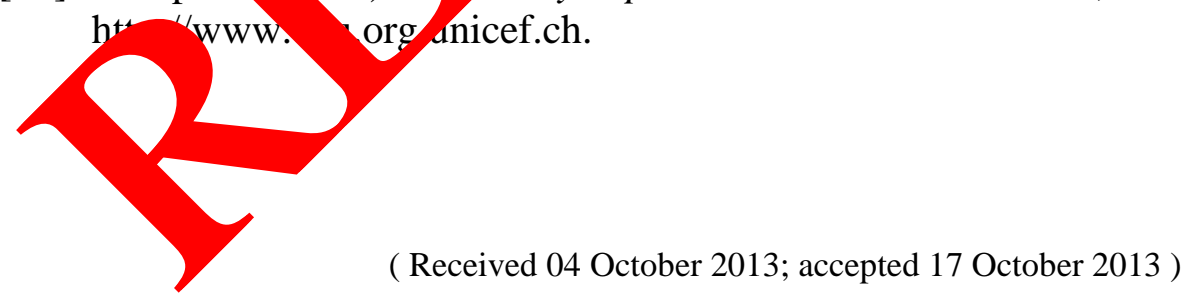

